ARCHEION, T. CXX

WARSZAWA 2019

ISSN 0066-6041

e-ISSN 2658-1264

DOI 10.4467/26581264ARC.19.009.11818

WANDA KRYSTYNA ROMAN

ORCID $\underline{0000-0002-5648-4273}$

wandakr@umk.pl

(Uniwersytet Mikołaja Kopernika w Toruniu)

\title{
ABY PAMIĘĆ NIE ZGINĘŁA? POLSKIE ARCHIWUM WOJENNE (1915-1921) I JEGO ZBIORY
}

Słowa kluczowe: Polskie Archiwum Wojenne, Centralna Biblioteka Wojskowa, I wojna światowa, straty wojenne

\section{Streszczenie}

Polskie Archiwum Wojenne (PAW) jest dzisiaj nieco zapomnianym przykładem na niezwykle popularne współcześnie zjawisko oddolnych inicjatyw obywatelskich, których efektem jest powoływanie archiwów społecznych. Archiwum powstało w wyniku społecznej inicjatywy grupy polskich historyków, archiwistów i bibliotekarzy zapoczątkowanej w styczniu 1915 r. w Wiedniu, a formalnie zakończonej w 1921 r. w Warszawie. Komitet i Zarząd PAW kierowały pracami związanymi z dokumentowaniem szeroko rozumianego uczestnictwa Polaków w I wojnie światowej oraz jej wpływu na gospodarkę, kulturę, obyczaje, stan umysłów i nastroje. Akcja realizowana była poprzez organizowane w terenie komitety, delegatury i ekspozytury PAW (na ziemiach polskich i za granicą) oraz wspomagana intensywną propagandą w postaci tysięcy odezw i ulotek. Efektem kilkuletniej społecznej pracy było zgromadzenie kilkuset rękopisów, kilku tysięcy tomów czasopism, prawie 100 tys. wycinków prasowych, kilkudziesięciu tysięcy odezw i afiszów, kilku tysięcy broszur oraz map, pocztówek i klisz, które przyszłym pokoleniom miały służyć jako świadectwo wojennego wysiłku Polaków. W okresie międzywojennym zbiory przechowywano i opracowywano w Centralnej Bibliotece Wojskowej (CBW). Wraz z gmachem i zbiorami CBW zbiory PAW spłonęły wskutek niemieckich bombardowań Warszawy w końcu września 1939 r. Pieczołowicie pielęgnowana pamięć o jednej wojnie uległa zagładzie podczas II wojny światowej. 
WANDA KRYSTYNA ROMAN

ORCID $\underline{0000-0002-5648-4273}$

wandakr@umk.pl

(Nicolaus Copernicus University in Toruń)

\title{
SAVING MEMORY FROM OBLIVION? POLISH WAR ARCHIVE (1915-1921) AND ITS COLLECTIONS
}

\author{
Keywords: Polish War Archive, Central Military Library, World War I, war losses
}

\begin{abstract}
The Polish War Archive (PAW) today is a somewhat forgotten example of the phenomenon which is extremely popular nowadays: grassroots civic initiatives which result in establishing social archives. It was created as a result of a social initiative of a group of Polish historians, archivists and librarians, initiated in January 1915 in Vienna and formally completed in 1921 in Warsaw. The Committee and the Board of PAW managed the work related to documenting the broadly understood participation of Poles in the World War I and its influence on the economy, culture, customs, state of mind and moods. The action was carried out through field committees, delegations and field units of PAW (both in Poland and abroad) and was supported by intensive propaganda in the form of thousands of proclamations and leaflets. The result of several years of social work was the collection of several hundred manuscripts, several thousand volumes of magazines, almost one hundred thousand press clippings, several tens of thousands of proclamations and posters, several thousand brochures and maps, postcards and films, which were to serve as testimony to the wartime effort of Poles for future generations. In the interwar period the collections were stored and developed in the Central Military Library (CML). The PAW collection burned down together with CML's collection and the building itself as a result of the German bombardment of Warsaw at the end of September 1939. The meticulously preserved memory of one war was annihilated during the Second World War.
\end{abstract}


I wojna światowa, która dla Polaków wiązała się z nadzieją na odzyskanie państwowości, trwała już od kilku miesięcy, kiedy grupa światłych przedstawicieli nauki historycznej uznała, że warto dla przyszłych pokoleń udokumentować polskie uczestnictwo w wojnie, pozostawić ślady materialne, dowody nie tylko na udział i męstwo w walce, ale jak i czym żyło ówczesne społeczeństwo, jak działania wojenne wpłynęły na gospodarkę, kulturę, obyczaje, stan umysłów i nastroje. Realizacją tego pomysłu miało zająć się Polskie Archiwum Wojenne (dalej: PAW), którego byt organizacyjny rozpoczął się w 1915 r. w Wiedniu, a zakończył w $1921 \mathrm{r}$. Jest ono dzisiaj nieco zapomnianym przykładem na niezwykle popularne współcześnie zjawisko oddolnych inicjatyw obywatelskich, których efektem jest powoływanie archiwów społecznych ${ }^{1}$. Literatura przedmiotu dotycząca dziejów PAW jest więcej niż skromna. Do dzisiaj powstał jeden artykuł naukowy ${ }^{2}$ oraz krótkie wzmianki w większych opracowaniach ${ }^{3}$. Głównym źródłem informacji są publikowane broszury i odezwy $\mathrm{PAW}^{4}$ oraz prasa polska z lat I wojny światowej i okresu międzywojennego ${ }^{5}$. Celem artykułu jest przypomnienie idei przyświecającej powołaniu społecznego Polskiego Archiwum Wojennego jako instytucji pamięci, przedstawienie jego działalności, dziejów gromadzenia i opracowania zbiorów w okresie międzywojennym oraz ich charakterystyka oraz losy po wybuchu II wojny światowej.

Wybuch I wojny światowej spowodował, że wielu przedstawicieli polskiego naukowego środowiska historycznego zostało wyrwanych ze swoich normalnych warunków życia i pracy. Ewakuacja dotknęła zarówno środowisko warszawskie, jak i krakowskie i lwowskie. W sierpniu 1914 r. duża grupa historyków lwowskich, wśród których byli m.in. Oswald Balzer, Władysław Semkowicz, Eugeniusz Barwiński, wyjechała do Wiednia, gdzie starała się kontynuować -

${ }^{1}$ Celem archiwów społecznych jest gromadzenie, przechowywanie, opracowywanie oraz udostępnianie dokumentacji nie będącej przedmiotem zainteresowania archiwów państwowych oraz nie wchodzącej do państwowego zasobu archiwalnego.

2 J. Semkowiczowa, Polskie Archiwum Wojenne (Dzieje instytucji), „Archeion” 1966, t. 45, s. 63-74. Autorka korzystała przede wszystkim ze zbiorów prasy z lat I wojny światowej i międzywojennych, ale również dokumentów męża, Władysława Semkowicza, pomysłodawcy, współtwórcy i propagatora PAW.

${ }^{3}$ Np. J. Maternicki, Idee i postawy. Historia i historycy polscy 1914-1918, Warszawa 1975, s. 498-499; B. Bartczak, Stanisław Zieliński, bibliotekarz, bibliograf, publicysta, Torun 1998; W.K. Roman, Centralne Archiwum Wojskowe 1918-1998 - tradycje, historia, współczesność stużby archiwalnej Wojska Polskiego, Torun 1999, s. 13-14.

${ }^{4}$ Najważniejsze to: Cele i zadania Polskiego Archiwum Wojennego, druk, Kraków 1917; Sprawozdanie Zarzadu Polskiego Archiwum Wojennego (1915-1916) (od 17 stycznia 1915 do 31 grudnia 1916), druk, Kraków 1917.

5 M.in. artykuły: W. Witwicki, Polskie Archiwum Wojenne, „Ilustrowany Tygodnik Polski” (Kraków), nr 6, z 5 września 1915 r., s. 98-99; W. Semkowicz, Polskie Archiwum Wojenne, „Tygodnik Literacko-Społeczny Pion" [Warszawa] 1935, r. 3, nr 23(88), s. 12; oraz ulotki i odezwy PAW ukazujące się m.in. na łamach różnych tytułów prasowych. 
z różnym skutkiem - pracę naukową ${ }^{6}$. To grono wybitnych uczonych podjęło spektakularną i bezprecedensową próbę ratowania i zachowania dla przyszłych pokoleń źródeł do przebiegu wojny i jej znaczenia dla sprawy polskiej. Wcześniej, tuż po wybuchu wojny, kilka instytucji naukowych, w tym Biblioteka Jagiellońska w Krakowie, Ossolineum, Archiwum Miejskie we Lwowie, Muzeum Etnograficzne w Poznaniu i Archiwum Akt Grodzkich i Ziemskich we Lwowie, zaapelowały do społeczeństwa o zbieranie druków i rękopisów związanych ze sprawą polską i udziałem Polaków w wojnie ${ }^{7}$. Jednak dopiero społeczna inicjatywa grupy polskich uczonych zapoczątkowana w Wiedniu przyniosła efekty prawdopodobnie przekraczające ich wyobrażenia.

W „wąskiej, zacisznej uliczce śródmieścia wiedeńskiego, zamkniętej gotycką sylwetką kościelnej absydy, w starym pamiątkowym domu o szerokiej, sklepionej bramie, wśród szeregu komitetów wychodźczych, jakie się w nim cisną, znalazło przytułek i Polskie Archiwum Wojenne" - pisał dr Władysław Witwic$\mathrm{ki}^{8}$, jeden z grupy polskich naukowców, którzy 17 stycznia $1915 \mathrm{r}$. w Wiedniu, w siedzibie Domu Polskiego, z inicjatywy dr. Stefana Vrtela ${ }^{9}$ lub Władysława Semkowicza ${ }^{10}$, powołali komitet, którego celem było zbieranie materiałów historycznych, ,gromadzenie dla przyszłego dziejopisarstwa dokumentów i pamiątek dotyczących udziału Polaków w wojnie światowej i skutków jej dla Polski" "11. Komitet ten dał początek instytucji naukowej nazwanej Polskim Archiwum Wojennym, chociaż zakładano, że nie będzie to statutowe towarzystwo (organizacja społeczna), ale „zespół pracowników pod kierunkiem Prezydium honorowego i zarządu, organizujących zbieranie i konserwację materiałów archiwalnych" 12 .

W pierwszej odezwie Komitetu, opublikowanej jako ulotka, oraz w prasie polskiej i niemieckiej, wystosowano apel, „by przyszłym przekazać jak najwięcej rzetelnych świadectw obecnych wydarzeń, aby historii, tej mistrzyni życia, co kiedyś odtwarzać będzie chwilę dzisiejszą, dostarczyć jak najobfitszego materiału do wyświetlenia udziału Polski w wojnie światowej i wykazania jej skutków dla narodu i ziemi naszej" ${ }^{13}$. Jednym z ważnych argumentów na rzecz zabezpieczenia materiałów dla przyszłego dziejopisarstwa była możliwość podjęcia działania świadomego i planowego, aby historyk zamiast przypadkowego i fragmentarycznego zasobu otrzymał w miarę kompletny zestaw dokumentów

6 J. Maternicki, op.cit., s. 83.

7 B. Waligóra, Zarys wysiłku około gromadzenia pamiętników, wspomnień, relacyj itp. do historii przedwojennych polskich związków wojskowych, formacyj i wojska polskiego, Warszawa 1938, mps na prawach rkps, s. 4.

${ }^{8}$ W. Witwicki, op.cit., s. 98.

9 Sprawozdanie Zarzadu Polskiego Archiwum Wojennego..., s. 6.

10 J. Semkowiczowa, op.cit., s. 63.

11 Nauka Polska, jej potrzeby, organizacja i rozwój, t. 2, Warszawa 1919, s. 584.

12 Sprawozdanie Zarząu Polskiego Archiwum Wojennego..., s. 7.

13 Odezwa Komitetu, [1915], oryginał w zbiorach Centralnego Archiwum Wojskowego (dalej: CAW), kopia, [w:] W.K. Roman, op.cit., załącznik 1. 
do badań. Nawoływano do pośpiechu, aby cenne materiały nie uległy zniszczeniu, aby gromadzić wszystko dla przekazania potomności nie na pamiątkę, ale dla pożytku i nauki ${ }^{14}$, gdyż wojna ,z jednej strony stwarza obfite materiały historyczne, a z drugiej przyczynia się do rychłej ich zatraty"15.

$\mathrm{Na}$ czele PAW stało prezydium honorowe w składzie ${ }^{16}$ : dr Oswald Balzer, profesor Uniwersytetu Lwowskiego, ks. dr Władysław Bandurski, bp sufragan lwowski, ks. Kazimierz Chłędowski, historyk, dr Kazimierz Kostanecki, rektor Uniwersytetu Jagiellońskiego, dr Kazimierz Twardowski, rektor Uniwersytetu Lwowskiego, dr Bolesław Ulanowski, profesor Uniwersytetu Jagiellońskiego, sekretarz Akademii Umiejętności ${ }^{17}$. Później dołączył do prezydium dr Ludwik Finkel, profesor Uniwersytetu Lwowskiego i prezes Towarzystwa Historycznego we Lwowie, oraz dr Józef Kallenbach, profesor Uniwersytetu Lwowskiego i prezes Towarzystwa Literackiego im. A. Mickiewicza we Lwowie.

Bieżącymi pracami PAW kierował zarząd, w którym zasiadali ${ }^{18}$ : faktyczny inicjator i twórca całego przedsięwzięcia dr Władysław Semkowicz jako przewodniczący, dr Stefan Vrtel-Wieczyński - jego zastępca i kustosz, dr Jan St. Bystron - sekretarz, Stefan Mękarski - zastępca sekretarza (później Helena Gałkówna), dr Marian Janelli - skarbnik, Bronisław Kryczyński - zastępca skarbnika, dr Franciszek Smolka - bibliotekarz, oraz dr Bronisław Pawłowski - archiwariusz.

Po powołaniu PAW ustalono, że w przyszłości docelowym miejscem dla zbiorów będzie stolica państwa polskiego, gdzie, jak już od 1915 r. planowano, zostanie powołane Polskie Archiwum i Muzeum Wojenne ${ }^{19}$ (lub Polskie Archiwum i Muzeum Wojny Światowej ${ }^{20}$ ). Działalność w terenie Komitet prowadził za pomocą placówek tworzonych w różnych miastach: delegatur, komitetów lokalnych, sekcji, które „zakładano „wszędzie, gdzie tętni życie polskie i gdzie sprawa polska budzi zajęcie, zarówno w kraju, jak i na obczyźnie"21. Ogółem sieć terenowa PAW obejmowała ponad 50 placówek $^{22}$, najwięcej na ziemiach Królestwa Polskiego i Galicji, ale działania szybko objęły również Śląsk i Wielkopolskę oraz ziemię wileńską. W miejscach tych gromadzono różne materiały, które następnie przesyłano do tzw. centralnego zbioru w Krakowie. Ekspozyturami kierowały osoby upoważnione przez PAW. Już po upływie półtora roku

\footnotetext{
${ }^{14}$ Ibidem.

15 Sprawozdanie Zarzadu Polskiego Archiwum Wojennego..., s. 5.

${ }^{16}$ Cele i zadania Polskiego Archiwum Wojennego..., s. 7.

17 Odezwa Komitetu...

18 Sprawozdanie Zarzadu Polskiego Archiwum Wojennego..., s. 8.

19 Polskie Archiwum Wojenne, ulotka, lipiec 1916 r., https://polona.pl/item/polskie-archiwum-wojenne-inc-wojna-swiatowa-powolala-do-zycia-szereg-nowych,NTkyODI3OTc/0/\#info:metadata [dostęp: 08.09.2018].

${ }^{20}$ Odezwa Komitetu...

${ }^{21}$ Ibidem.

${ }^{22}$ W. Semkowicz, Polskie Archiwum Wojenne..., s. 12.
} 
działały komitety na ziemiach polskich: w Krakowie, Lwowie, Warszawie, Poznaniu, Lublinie, Wilnie, Przemyślu. Po przybyciu do Lwowa Semkowicza, we wrześniu 1915 r., tam ulokował się zarząd organizacji, kierując pracami wszystkich delegatur. Z inicjatywy lokalnych działaczy powstawały nowe struktury terenowe. Na przykład profesor gimnazjum przemyskiego i działacz Towarzystwa Przyjaciół Nauk Feliks Przyjemski, przebywając w Wiedniu, nawiązał kontakt z działaczami PAW i 5 sierpnia 1915 r. otrzymał legitymację z upoważnieniem do zbierania darów. Rok później prawdopodobnie dzięki niemu powołano w Przemyślu komitet PAW ${ }^{23}$. Siedziby terenowych ekspozytur PAW ulegały zmianie wraz ze zmianą warunków wojennych, zmianami przebiegu linii frontów oraz zasięgu poszczególnych okupacji ziem polskich. Za granicą powołano komitety w Wiedniu, Fryburgu w Szwajcarii i Kijowie oraz delegatury w Berlinie, Budapeszcie, Sofii, Konstantynopolu, Hadze, Kopenhadze, Sztokholmie i Bukareszcie $^{24}$. Komitet wiedeński w 1915 r. liczył 85 osób. Zorganizowano również ekspozytury w Pradze i Zakopanem. Wiedeński komitet zajmował się m.in. kompletowaniem prasy polskiej i niemieckiej, a Komitet we Fryburgu, oprócz gromadzenia materiałów, podejmował akcję organizatorską $\mathrm{w}$ tych krajach, z którymi wskutek wojny kontakty były niemożliwe lub znacznie utrudnione ${ }^{25}$. Wszystkie struktury zagraniczne po kilku latach zamknięto. Oprócz placówek terenowych PAW miało również delegatów w Legionach Polskich ${ }^{26}$.

Deklarowano, że cele postawione przed PAW można osiągnąć jedynie z dala od wszelkiej polityki, jednak nie okazało się to do końca możliwe. Wśród członków prezydium i zarządu PAW przeważali zwolennicy orientacji na państwa centralne. Na przykład Oswald Balzer szybko nawiązał współpracę z Naczelnym Komitetem Narodowym (NKN) w Krakowie, którego został członkiem ${ }^{27}$. W Komisji Archiwalnej Tymczasowej Rady Stanu zasiadał Semkowicz, który był jednym z opiniodawców projektów regulaminów i ustawy archiwalnej, spożytkowanych później przy opracowywaniu Reskryptu Rady Regencyjnej o organizacji archiwów państwowych i opiece nad archiwaliami ${ }^{28}$. Także w Radzie Stanu powstał referat PAW, kierowany przez Vrtel-Wieczyńskiego, który koordynował akcję zbierania materiałów z Królestwa Polskiego, a zwłaszcza z Warszawy ${ }^{29}$. Działalność polityczna umożliwiała propagowanie idei PAW. Dlatego jednym z obszarów pozyskiwania zbiorów były polskie formacje wojskowe oraz polskie komitety narodowe. Już

\footnotetext{
${ }^{23}$ Z. Konieczny, Dzieje archiwum przemyskiego i jego zasobu, Przemyśl 1989, s. 46-47.

${ }^{24}$ Polskie Archiwum Wojenne, ulotka.

${ }^{25}$ Polskie Archiwum Wojenne, „Kurier Lwowski” z 15 sierpnia 1915 r., https://zbruc.eu/ node/40386 [dostęp: 10.09.2018].

${ }^{26}$ Sprawozdanie Zarzadu Polskiego Archiwum Wojennego..., s. 32.

27 J. Maternicki, op.cit., s. 188-189.

${ }^{28}$ Ibidem, s. 480. Treść Reskryptu Rady Regencyjnej w całości weszła do Dekretu o archiwach państwowych i opiece nad archiwaliami z 7 dnia lutego 1919 r., stanowiącego aż do 1951 r. podstawę prawną działalności archiwalnej w Polsce.

${ }^{29}$ W. Semkowicz, Polskie Archiwum Wojenne..., s. 12.
} 
w 1915 r. prezydium krakowskiego NKN zadeklarowało gotowość do oddania swoich akt po ich zamknięciu do zbiorów PAW. Wkrótce, po zdobyciu przychylności Komendy Legionów Polskich, uzyskano pisemną obietnicę szefa sztabu, że po wykorzystaniu materiałów wojennych, dotyczących działalności Legionów, chętnie odda wszystkie akta PAW „do pieczołowitego przechowania" ${ }^{30}$. Przychylność dla idei PAW w sierpniu 1915 r. zadeklarowało Towarzystwo Historyczne we Lwowie, gdzie po przybyciu Semkowicza miał powstać Komitet dla Galicji Wschodniej ${ }^{31}$. Pomoc zaoferował również Wydział Krajowy Sejmu Galicyjskiego, który w prasie zachęcał marszałków powiatowych i burmistrzów do współdziałania na rzecz $\mathrm{PAW}^{32}$. Z kolei Rada Szkolna Krajowa Galicji poparła akcję zbierania materiałów w instytucjach oświatowych.

Podstawy finansowe PAW opierały się na dobrej woli i ofiarności nielicznych osób prywatnych oraz instytucji prywatnych i publicznych. Zakładano, że część materiałów trzeba będzie kupować, a przechowywanie zbiorów również będzie kosztować. Prawie od początku podnoszono, że w innych krajach to rządy ponoszą koszty gromadzenia zbiorów wojennych, a Polacy mogą liczyć jedynie ma dobrą wolę i ofiarność nielicznych osób ${ }^{33}$. PAW wspierały subwencjami pieniężnymi m.in.: Towarzystwo Popierania Nauki Polskiej, Rada miasta Lwowa, galicyjski Bank Hipoteczny, Towarzystwo Ubezpieczeń Urzędników Prywatnych we Lwowie, Naczelny Komitet Narodowy oraz indywidualni darczyńcy, jak dr Juliusz Twardowski, radca dworu przy cesarskim Ministerium ds. Galicji3i ${ }^{34}$. Jednorazowe datki pieniężne, oprócz składek miesięcznych, wpłacali niejednokrotnie członkowie Komitetu honorowego oraz Zarządu PAW. Składki miesięczne członków komitetów, darowizny pieniężne i zasiłki doraźne nie wystarczały na pokrycie znacznych wydatków szeroko zakrojonej akcji, dlatego sięgano po inne sposoby zdobywania funduszy, jak odczyty naukowe, z których część dochodu dodatkowo przekazywano na cele dobroczynne. Podczas odczytów i wykładów zawsze apelowano do słuchaczy o wspomaganie dzieła PAW materiałami źródłowymi. Sprzedawano również karty pocztowe oraz pobierano opłaty za odznaki PAW. Odwoływano się do społeczeństwa, na którego stałą pomoc, nawet drobne datki, liczono najbardziej, słusznie podkreślając, że tylko ono może zastąpić w istniejących warunkach opiekę państwa.

Polskie Archiwum Wojenne prowadziło intensywną propagandę m.in. w formie, drukowanych w tysiącach egzemplarzy, odezw i komunikatów prasowych, nawołując do gromadzenia różnych dokumentów, książek, czasopism, ale również pisania wspomnień, zbierania opowieści, podań, pieśni wojennych, pamiętników i innych pamiątek. Gazety nieodpłatnie udostępniały swoje łamy dla

\footnotetext{
${ }^{30}$ Sprawozdanie Zarzadu Polskiego Archiwum Wojennego..., s. 14.

${ }^{31}$ Sprawy Towarzystwa, „Kwartalnik Historyczny” 1915, nr 29, s. 480.

${ }^{32}$ Polskie Archiwum Wojenne, „Kurier Lwowski”...

${ }^{33}$ Polskie Archiwum Wojenne, ulotka...

${ }^{34}$ Ibidem.
} 
zamieszczania apeli do społeczeństwa. Między innymi wydawany w Krakowie przez NKN „Ilustrowany Tygodnik Polski” wielokrotnie od 1915 r. zamieszczał artykuły i apele popularyzujące akcję PAW. Komitet abonował również niektóre gazety i czasopisma oraz wycinki z gazet obcych, jeśli dotyczyły sprawy polskiej. Jak pisze Jadwiga Semkowiczowa, żona głównego inicjatora PAW, posiadająca zapewne informacje z pierwszej ręki, o wiele bardziej skuteczne były jednak kontakty osobiste niż akcja propagandowa w prasie i ulotkach ${ }^{35}$.

Akcja PAW nie miała jedynie charakteru biernego gromadzenia. Komitet i zarząd inicjowały tworzenie różnych źródeł, np. nawołując do pisania pamiętników i dzienników. Propagowaniu idei PAW miały służyć specjalnie wydawane instrukcje: w sprawie zbierania materiałów do folkloru wojennego w postaci kwestionariusza oraz dla piszących wspomnienia, dzienniczki i pamiętniki ${ }^{36}$. Do komitetów i delegatur terenowych wysyłano instrukcje, jak nawiązywać stosunki z żołnierzami, osobami cywilnymi, które mogłyby stać się twórcami cennych źródeł. Odezwa w sprawie zbierania materiałów do folkloru wojennego ukazała się drukiem m.in. na łamach „Głosu Rzeszowskiego" latem 1917 r. ${ }^{37}$ Powołując się na podobne inicjatywy zagraniczne, apelowano o gromadzenie materiałów ludoznawczych, jako tych, które w znaczący sposób mogą uzupełnić dokumentację administracyjną, formalną. Zwracano uwagę np. na fakt, że zwyczajni żołnierze, często pochodzący ze środowiska chłopskiego, rzuceni w nowe warunki, otoczeni różnymi ludźmi, wyrabiają sobie nowe poglądy, wierzenia i praktyki, tworzą nowe pieśni, a nawet specjalny język. W pomocniczym kwestionariuszu zapytywano m.in. o ludowe wróżby, przepowiednie i znaki dotyczące wojny, zwyczaje związane z pożegnaniem odchodzących na wojnę oraz ich wyposażenie skierowane na ochronę życia - szkaplerze, obrazki, medaliki.

Instrukcję dla piszących pamiętniki i wspomnienia opracowała sekcja pamiętnikarska PAW kierowana przez Władysława Witwickiego, wskazując na formę i treść tworzonych źródeł, aby mogły w przyszłości stać się rzetelnym materiałem dla badań naukowych ${ }^{38}$. Przede wszystkim zwracano uwagę potencjalnych autorów, aby nie skupiali się na aspektach polityczno-militarnych, ale opisywali sprawy kultury, gospodarki (funkcjonowanie różnych instytucji, jak banki, warsztaty, sklepy, sprawy cen towarów, stosunki pracowników i pracodawców w mieście i na wsi), oświaty, prądów umysłowych, zwyczajów i obyczajów, stronę psychologiczną wojny i nastroje niezależnie, jakiego obszaru i miejsca dotyczy oraz z jakiego punktu widzenia patrzy opisujący. Jako samo-

\footnotetext{
${ }^{35}$ J. Semkowiczowa, op.cit., s. 66.

${ }^{36}$ B. Waligóra, op.cit., s. 6.

${ }^{37}$ Odezwa w sprawie zbierania materiałów do folkloru wojennego, „Głos Rzeszowski” z 1 lipca 1917 r., http://www.wycinki.olejow.pl/?p=7361 [dostep: 13.09.2018].

${ }^{38}$ Instrukcya Komitetu Polskiego Archiwum Wojennego (dla piszacych wspomnienia, dzienniczki i pamiętniki), druk, [1915] s. 1. Druk zachował się w zbiorach Książnicy Cieszyńskiej, https://www. sbc.org.pl/dlibra/show-content/publication/edition/177348?id=177348 [dostęp: 17.04.2018].
} 
dzielne druki wydano również odezwę „O wojenną twórczość ludową” oraz „Do kobiet polskich".

Celem nadrzędnym utworzenia PAW było zbieranie ,wszystkiego, co ma jakikolwiek, bezpośredni lub pośredni związek z udziałem Polski w wojnie światowej" ${ }^{39}$, co dotyczy skutków i wpływu wojny na ziemie i społeczeństwo polskie oraz na rozwój sprawy polskiej. Uważano, że nie można oczekiwać biernie na koniec wojny, ale należy „cały materiał dla przyszłego dziejopisarstwa gromadzić współcześnie z wypadkami, żeby był na gorąco chwytany i w archiwach składany" ${ }^{40}$. Zwracano uwagę, że w rękach prywatnych jest wiele pamiątek, dokumentów, z których kolejne pokolenia mogłyby czerpać „naukę i przestrogę, otuchę i przykłady męstwa" "41, tymczasem są one całkowicie bezużyteczne. Jednak skoro powstało PAW, to „obowiązkiem jest wszystkich tę instytucję, jako ważną placówkę narodową, wszechstronnie popierać i wzbogacać”, a „liczni zbieracze prywatni wzniosą się ponad pobudkę osobistej przyjemności i przeznaczając zbiory swe dla instytucji publicznych, zaskarbią sobie wdzięczność i pamięć potomnych"42.

Zbierany materiał grupowano w trzech częściach: druki, rękopisy oraz muzealia. Do druków zaliczono książki, broszury, druki ulotne, odezwy, obwieszczenia, afisze, programy, zaproszenia, klepsydry, czasopisma polskie i zagraniczne w całości lub wycinki. W grupie rękopisów gromadzono pamiętniki, wspomnienia, zapiski, listy osób, które „przeżywały wypadki wojenne”, karty polowe, wykazy statystyczne i sprawozdania dotyczące stosunków gospodarczych i kulturalnych, nieogłoszone drukiem pieśni żołnierskie, wszelkiego rodzaju akta dotyczące dziejów polskich komitetów narodowych, organizacji militarnych oraz komitetów uchodźczych. Wśród muzealiów znalazły się ilustracje, fotografie, widokówki, znaczki pocztowe, bony wojenne, noty bankowe, pieczątki, mapy (niektóre materiały współcześnie uznajemy za materiały archiwalne), odznaki okolicznościowe, pierścionki, medale pamiątkowe, monety, plakiety, utwory muzyczne, wreszcie broń wszelką, rynsztunek i mundury ${ }^{43}$. Najszybciej powiększał się dział czasopism, pokaźne rozmiary zyskał szybko dział pism ulotnych, odezw, afiszów, ogłoszeń. Najsłabiej rozwijał się dział biblioteczny i muzealny, których zbiory wymagały przede wszystkim funduszy oraz aktywniejszego i świadomego współdziałania ze strony obywateli.

Początkowo zbiory centralne gromadzono w Wiedniu, najpierw w lokalu przekazanym przez Centralny Komitet Opieki nad Wychodźcami, potem w nieco lepszych warunkach przy ul. Wallnerstrasse nr 1-a. Po przeniesieniu się Zarządu PAW do Lwowa we wrześniu 1915 r. zbiorami wiedeńskimi zaopiekował

\footnotetext{
${ }^{39}$ Sprawozdanie Zarzadu Polskiego Archiwum Wojennego..., s. 8.

${ }^{40}$ Ibidem, s. 5.

${ }^{41}$ Polskie Archiwum Wojenne, ulotka...

42 Ibidem.

${ }^{43}$ Sprawozdanie Zarzadu Polskiego Archiwum Wojennego..., s. 8.
} 
się miejscowy komitet PAW. Natomiast od jesieni 1916 r. główne zbiory gromadzono w Krakowie w gmachu Akademii Umiejętności przy ul. Sławkowskiej 17, gdzie już wcześniej składały zebrane przez siebie materiały ekspozytury z miast małopolskich i gdzie później przeniesiono większą część zasobów z Wiednia i Lwowa ${ }^{44}$. Do Krakowa, po rocznej działalności we Lwowie, przeniósł się również Zarząd PAW (we Lwowie ukonstytuował się miejscowy komitet PAW), co związane było z otrzymaniem przez prezesa Semkowicza, katedry historii średniowiecznej na Uniwersytecie Jagiellońskim ${ }^{45}$.

Od początku wysuwano postulat skoncentrowania materiałów archiwalnych w jednym miejscu, aby przyszłym badaczom ułatwić korzystanie ze zbiorów, „,W jednym, wielkim ognisku archiwalnym i muzealnym" na wzór centralnych zbiorów wojennych tworzonych w innych państwach i miastach Francji, Berlinie, Wiedniu i innych stolicach państw walczących ${ }^{46}$. Postanowiono, że powołane w przyszłości w stolicy „Centralne Archiwum i Muzeum Wojny powinno wchłonąć w siebie [oprócz zbiorów PAW - W.K. R.] w przyszłości archiwa wszystkich organizacji narodowych, tak wojskowych, jak i politycznych i humanitarnych działających w czasie wojny zarówno na terenie ziem polskich, jak i za granicą" ${ }^{47}$. Był to plan ogromnego archiwum ze zbiorami obejmującymi różne dziedziny życia polskiego społeczeństwa podczas wojny, ale archiwum społecznego. Komitet PAW bowiem zdawał sobie sprawę z tego, że kiedy powstaną władze niepodległego państwa polskiego, będą one tworzyć własne archiwa, ale ich zainteresowanie obejmie przede wszystkim materiały oficjalne: instytucji i urzędów administracyjnych. Komitet zatem postawił sobie za cel ratowanie ,archiwów instytucji nieustalonych, efemerycznych, zagrożonych w swym istnieniu". Jednocześnie działał jako depozytariusz na rzecz przyszłego państwa polskiego w stosunku do materiałów, które zabezpieczał dla przyszłych archiwów polskich. Takim depozytem było wspomniane wcześniej, przyjęte do zbiorów PAW w lutym 1918 r., Archiwum Komendy Legionów w Krakowie ${ }^{48}$, które w objętości 36 skrzyń akt przekazano do dyspozycji Ministerstwa Spraw Wojskowych, i które ostatecznie w 1920 r. znalazło się w Centralnym Archiwum Wojskowym (później Archiwum Wojskowym) podlegającym temu resortowi ${ }^{49}$.

Warto zwrócić uwagę na status materiałów PAW, które mogły być kupowane, darowane, ale mogły również stanowić depozyt, do odebrania w każdej chwili. Dopuszczano również możliwość zrobienia kopii i zwrócenia oryginału właścicielowi. Ponadto „Komitet poręcza bezwzględną dyskrecję i zobowiązuje się publicznie nie czynić z nadesłanych materiałów innego użytku, jak tylko taki, na jaki ofiarodaw-

\footnotetext{
44 Ibidem, s. 30.

45 J. Semkowiczowa, op.cit., s. 70.

46 Sprawozdanie Zarzadu Polskiego Archiwum Wojennego..., s. 6.

47 Cele i zadania Polskiego Archiwum Wojennego..., s. 9.

48 W. Semkowicz, Polskie Archiwum Wojenne..., s. 12.

49 W.K. Roman, op.cit., s. 15.
} 
ca lub deponent zezwolił. Składający rękopis jakiś w Archiwum może być pewny, że pamiątka ta nie zginie, owszem przechowywana troskliwie, przyniesie pożytek i przyda się kiedyś naszym badaczom do odtworzenia obrazu bieżącej chwili"’50.

Zakończenie wojny i powstanie niepodległego państwa polskiego w listopadzie 1918 r. spowodowało potrzebę podjęcia decyzji co do dalszych losów zbiorów PAW. Prawie półtora roku wcześniej Komisja Archiwalna, powołana przy Departamencie Spraw Politycznych Tymczasowej Rady Stanu Królestwa Polskiego pod przewodnictwem prof. Marcelego Handelsmana, zainteresowała się PAW. W podjętej na posiedzeniu 20 czerwca 1917 r. uchwale doceniła doniosłość akcji PAW, podniosła potrzebę skoncentrowania zbiorów w jednym miejscu i konieczność objęcia ich opieką przez Radę Stanu przez utworzenie przy niej, wspomnianego już, specjalnego referatu ds. PAW, kierowanego przez dr. Vrtel-Wierczyńskiego ${ }^{51}$. Nie uznano za konieczne sprowadzanie zbiorów do Warszawy, mając na uwadze potrzebę zorganizowania w przyszłości instytucji archiwalnej, która zajęłaby się całością zbiorów z Warszawy i pozostałych terenów Królestwa Kongresowego. Wobec takiego stanowiska Zarząd PAW okazał wdzięczność, ale jednocześnie zdystansował się od podporządkowania Komisji Archiwalnej, pozostając przy dotychczasowym, społecznym charakterze zbiorów i nie widząc wówczas potrzeby przekazywania ich Radzie Stanu.

Sprawa wróciła dopiero po powołaniu Rady Regencyjnej, po uchwaleniu Reskryptu o organizacji archiwów państwowych i opiece nad archiwaliami ${ }^{52}$ i powołaniu, jako komórki organizacyjnej Ministerstwa Wyznań Religijnych i Oświecenia Publicznego, Wydziału Archiwów Państwowych (dalej: WAP), którego naczelnikiem mianowano prof. Stefana Ehrenkreutza. To wtedy powołano Wincentego Łopacińskiego na referenta do spraw PAW, a Władysława Semkowicza na członka Rady Archiwalnej ${ }^{53}$ działającej na podstawie Reskryptu Rady Regencyjnej ${ }^{54}$. W listopadzie i grudniu 1918 r. Rada Archiwalna zajęła się problemem PAW. Uchwałą Rady z 2 grudnia zbiory PAW przeszły pod zarząd Wydziału Archiwów Państwowych ${ }^{55}$, któremu wkrótce, mocą Dekretu o organizacji archiwów państwowych i opiece nad archiwaliami ogłoszonego 7 lutego 1919 r., powierzono zarządzanie archiwami w Rzeczypospolitej ${ }^{56}$. Zbiory PAW

\footnotetext{
${ }^{50}$ Instrukcya Komitetu Polskiego Archiwum Wojennego..., s. 2.

${ }^{51}$ Polskie Archiwum Wojenne. Sprawozdanie zarzadu za lata 1917-1918, „Gazeta Lwowska” 1919, nr 222, s. 3.

52 Reskrypt Rady Regencyjnej z dnia 31 lipca 1918 roku o organizacji archiwów państwowych i opiece nad archiwaliami, [w:] S. Sierpowski, D. Matelski, Dzieje archiwistyki polskiej. Wybór źródet, t. 1, Poznań 1988, s. 9-20.

${ }_{53}$ Rada Archiwalna była organem opiniującym normatywy archiwalne oraz doradczym w sprawach opieki nad archiwaliami, przewodził jej minister wyznań religijnych i oświecenia publicznego.

${ }^{54}$ Polskie Archiwum Wojenne. Sprawozdanie..., s. 3.

${ }_{55}$ R. Piechota, B. Jagiełło, M. Motas, Pierwsze protokoły Rady Archiwalnej (1918-1922), „Teki Archiwalne" 1971, t. 13, s. 128.

${ }^{56}$ S. Sierpowski, D. Matelski, op.cit., s. 31-40.
} 
umieszczono w magazynach przy ul. Długiej $13 \mathrm{w}$ Warszawie ${ }^{57}$, należących do, powołanego wspomnianym Dekretem, Archiwum Wojskowego funkcjonującego do 1925 r. w strukturze WAP ${ }^{58}$.

Konkretne decyzje zapadły podczas II sesji Rady Archiwalnej w dniach 8-12 lutego 1919 r. Wówczas Rada, „wychodząc z założenia, że akcja [...] ma niezwykłą doniosłość dla przyszłego dziejopisarstwa i uważając, że zaniedbanie tej sprawy przynieść może niepowetowane szkody, aprobując działalność Polskiego Archiwum Wojennego wzywa Wydział Archiwów Państwowych do postawienia sprawy PAW na odpowiednim poziomie" ${ }^{59}$. Zobowiązano Wydział do powierzenia PAW specjalnemu referentowi z dodaniem mu siły pomocniczej oraz wydania polecenia archiwistom objazdowym ${ }^{60}$, aby popierali akcję PAW $\mathrm{w}$ terenie, porozumiewając się z istniejącymi delegaturami PAW lub tworząc nowe. Wkrótce specjalnym referentem ds. PAW Wydział mianował dr. Wincentego Łopacińskiego ${ }^{61}$. Rada Archiwalna sugerowała, aby WAP postarał się o odpowiednie fundusze na wszystkie te prace oraz skierowała do Wydziału wniosek, aby podjął kroki w celu pozyskania do zbiorów PAW archiwum Zarządu Prasowego, pozostałego po okupacyjnym niemieckim Wojskowym Gubernatorze Łódzkim, zajmującym się nadzorem nad drukarniami i księgarniami oraz cenzurą wszystkich druków ${ }^{62}$. Władysław Semkowicz odczytał memoriał Zarządu PAW dotyczący włączenia zbiorów do projektowanego przez autorów memoriału Muzeum i Archiwum Walk o Niepodległość Narodu Polskiego, a Rada jednogłośnie przyjęła wniosek. WAP opracował odpowiedni projekt i przedstawił go Sejmowi $\mathrm{RP}^{63}$. Brak informacji o dalszych losach tego projektu, lecz wiadomo, że placówka taka nie powstała.

W 1919 r. Zarząd PAW przystąpił do zamykania pracy oddziałów i delegatur $^{64}$. W tym czasie określano zbiory zgromadzone w Krakowie jako pokaźne, ale stanowiące jedynie cząstkę tego, co posiadają placówki terenowe ${ }^{65}$. Zakłada-

${ }^{57}$ O tym fakcie pośrednio można wnioskować na podstawie rozkazu Dowództwa Okręgu Etapowego w Wilnie z 29 grudnia 1919 r., (będący powtórzeniem treści odezw PAW), nakazujący referentom oświatowym jednostek wojskowych gromadzenie materiałów archiwalnych i muzealnych odnoszących się do dziejów wojny współczesnej i odsyłanie ich na adres Polskiego Archiwum i Muzeum Wojskowego w Warszawie, ul. Długa 13. CAW, Kolekcja Wojskowej Komisji Archiwalnej, sygn. VIII. 807.29.4, k. 130-131, Rozkaz nr 29 z 29 grudnia 1919 r.

${ }^{58}$ E. Kołodziej, Zarys dziejów Archiwum Akt Nowych w latach 1919-2008, Warszawa 2008, s. $20-27$.

${ }^{59}$ R. Piechota, B. Jagiełło, M. Motas, op.cit., s. 117.

${ }^{60}$ Archiwiści objazdowi, powołani Reskryptem Rady Regencyjnej, co powtórzono w Dekrecie, byli to doświadczeni archiwiści skierowani do pracy w terenie, którzy poszukiwali, spisywali oraz zabezpieczali odnalezione archiwalia.

${ }_{61}$ W. Semkowicz, Polskie Archiwum Wojenne ..., s. 12.

${ }^{62}$ R. Piechota, B. Jagiełło, M. Motas, op.cit., s. 117.

${ }^{63}$ Ibidem, s 124-128.

${ }^{64}$ Polskie Archiwum Wojenne. Sprawozdanie..., s. 2.

${ }^{65}$ Ibidem. 
no, że stopniowo będą przesyłane do Krakowa lub do Warszawy jako miejsca docelowego. Do tego czasu były porządkowane przez życzliwych i bezinteresownych ochotników, m.in. słuchaczy Uniwersytetu Jagiellońskiego ${ }^{66}$. W siedzibach większych komitetów, jak np. lwowskiego, również podejmowano wstępne prace inwentaryzacyjne.

Dnia 1 stycznia 1921 r. PAW formalnie zamknęło gromadzenie bieżącego materiału, chociaż jeszcze wiele razy członkowie Zarządu PAW ogłaszali w prasie apele o przekazywanie pamiątek i materiałów z I wojny światowej ${ }^{67}$. Władysław Semkowicz formalnie pozostał prezesem Zarządu PAW do 1925 r., ale i później, aż do wybuchu II wojny światowej żywo interesował się losami zbiorów ${ }^{68}$. W dniu 14 marca 1922 r. WAP podjął decyzję o przekazaniu Centralnej Bibliotece Wojskowej (dalej: CBW) w Warszawie zbiorów archiwalno-bibliotecznych Polskiego Archiwum Wojennego obejmujących: 444 rękopisy, 4203 tomy czasopism, 84507 wycinków prasowych, 29998 odezw i afiszów, 7073 broszury oraz mapy, pocztówki i klisze ${ }^{69}$ spakowanych w 350 pakach $^{70}$. W dniu 16 kwietnia nastąpiło faktyczne przekazanie zbiorów w formie wieczystego depozytu pod nadzór dyrektora CBW ppłk. dr. Mariana Łodyńskiego na podstawie uchwały Rady Archiwalnej oraz specjalnej umowy z Zarządem PAW ${ }^{71}$. Muzealia PAW znalazły swoje miejsce także w Warszawie, w Muzeum Wojska Polskiego.

W strukturze CBW powstał nowy Oddział Polskiego Archiwum Wojennego, co było jednym z warunków umowy z Zarządem PAW. Trzy lata później w CBW powołano Komisję Stypendialną, której zadaniem było rozpisanie konkursu na skatalogowanie rękopisów i archiwaliów dotyczących dziejów wojskowości polskiej wchodzących m.in. w skład zbiorów PAW, a było to prawdopodobnie częścią szerszej akcji tworzenia ewidencji archiwaliów proweniencji wojskowej znajdujących się w zbiorach państwowych, publicznych i prywatnych, w archiwach i bibliotekach ${ }^{72}$. Stypendia ufundowane przez Towarzystwo Wiedzy Wojskowej otrzymali: Bronisław Komplikiewicz ze Lwowa, Wojciech Czerwiński z Krako-

66 J. Semkowiczowa, op.cit., s. 70.

${ }^{67} \mathrm{~Np}$. S. Wierczyński, Kto ma jakie pamiątki z czasu wojny światowej, „Kurier Poznański” nr 173, z 14 kwietnia 1928 r., s. 8, http://www.wbc.poznan.pl/dlibra/publication?id=77204\&tab=3 [dostęp: 17.09.2018]; W. Semkowicz, W sprawie gromadzenia materiałów z wojny światowej, „Nauka Polska, jej potrzeby, organizacja i rozwój” 1932, t. 16, s. 90, http://mbc.malopolska.pl/publication/73063 [dostęp: 17.09.2018]; Pomnażajmy zbiory Polskiego Archiwum Wojennego, „Ilustrowany Kurier Codzienny" nr 216 z 6 sierpnia 1934 r., s. 9, http://mbc.malopolska.pl/dlibra/publication/72613?tab=1 [dostęp: 17.09.2018].

68 J. Semkowiczowa, op.cit., s. 74.

${ }^{69}$ A. Gąsiorowska, M. Lewnau, K. Piwowarska, Centralna Biblioteka Wojskowa 1919-1999. Kalendarium, Warszawa 1999, s. 29.

70 J. Semkowiczowa, op.cit., s. 73.

${ }^{71}$ Kronika, „Przegląd Historyczno-Wojskowy” 1929, t. 1, s. 186.

72 B. Pawłowski, Stan i ogólna charakterystyka źródeł do polskiej historii wojskowej, [w:] O. Laskowski, B. Pawłowski, Badania dawnej polskiej historii wojskowej. Zadania pracy i ogólna charakterystyka źródel, Warszawa 1927, s. 27. 
wa, Janusz Staszewski z Poznania i Adam Markiewicz z Warszawy. Prawdopodobnie o nich jest mowa jako o pracownikach PAW, wymienianych odrębnie, poza pracownikami etatowymi CBW, opłacanych ze specjalnych funduszy do wykonania określonych prac. Systematyczne porządkowanie zbiorów PAW rozpoczęło się w $1927 \mathrm{r}^{73}$

W dziesięciolecie odzyskania niepodległości Zarząd PAW jeszcze raz zwrócił się z apelem do społeczeństwa, aby uzupełniać zbiory PAW i przekazywać do CBW dokumenty i pamiątki lat wojennych 1914-192074. W $1928 \mathrm{r}$. do czasopisma wojskowego „Bellona” dołączono wykaz posiadanych przez CBW tytułów i numerów czasopism $\mathrm{z}$ apelem o pomoc $\mathrm{w}$ ich kompletowaniu $^{75}$.

Opracowanie zbiorów postępowało i do 1928 r. skatalogowano wycinki prasowe, pisma ulotne oraz część rękopisów. W tym samym roku do CBW przyjechał przedstawiciel Hoover History Collection ${ }^{76}$, z którą to instytucją placówka prowadziła współpracę $\mathrm{w}$ zakresie wymiany dubletów ${ }^{77}$. Był zainteresowany metodyką opracowania zbiorów PAW na tyle, że zaproponował pokrycie połowy kosztów tego przedsięwzięcia w zamian za odpis jednego egzemplarza przygotowanego inwentarza ${ }^{78}$. Ten katalog zbiorów PAW znajduje się w Hoover Institution Archives w Stanford (Kalifornia, USA) ${ }^{79}$ i jest prawdopodobnie jednym z niewielu zachowanych dowodów na ogromną pracę dokumentacyjną wykonaną przez społeczeństwo polskie dla ocalenia pamięci własnego udziału w I wojny światowej.

W 1928 r. Ministerstwo Spraw Wojskowych przyznało specjalny kredyt na uporządkowanie zbiorów PAW. Materiały początkowo podzielono na dwa działy: wycinki prasowe, afisze, pisma ulotne, prasa krajowa i zagraniczna oraz rękopisy ${ }^{80}$, ale wkrótce wydzielono ich sześć: 1 . rękopisy, 2. czasopisma i wycinki z czasopism, 3. afisze, odezwy i rozporządzenia władz, 4. Prasa okopowa, jednodniówki i prasa ulotna, 5. Broszury, 6 . Klisze, pocztówki, mapy i in.$^{81} \mathrm{~W}$ tym czasie do grona opracowujących dołączyła Regina Oppmanowa, absolwentka studiów historycznych i kursu archiwalnego organizowanego przez WAP ${ }^{82}$. Kolejnym krokiem zmierzającym do udostępnienia materiałów użytkownikom

${ }^{73}$ Kronika..., s. 187.

${ }^{74}$ Ibidem.

75 Ibidem.

${ }^{76}$ Kronika CBW, „Komunikat Bibliograficzny” 1926, nr 1.

${ }^{77}$ E. Horodyska, Centralna Biblioteka Wojskowa w latach 1919-1932 i jej rola w organizacji bibliotek wojskowych w Polsce, Warszawa 1966, s. 26-31.

${ }^{78}$ A. Gąsiorowska, M. Lewnau, K. Piwowarska, op.cit., s. 35.

${ }^{79}$ Został opisany jako: Polish Military Archives, Catalog of pamphlets, leaflets and periodicals at the archives, http://www.oac.cdlib.org/findaid/ark:/13030/kt9m3nf3sj/ [dostęp: 10.03.2018].

${ }^{80}$ A. Gąsiorowska, M. Lewnau, K. Piwowarska, op.cit., s. 46.

81 J. Semkowiczowa, op.cit., s. 73.

82 S.K. Kuczyński, Regina Oppmanowa (29 I 1905-15 IX 1980), „Archeion” 1982, t. 74, s. 248. 
biblioteki było opracowanie i wydanie w $1930 \mathrm{r}$. instrukcji do porządkowania druków ulotnych Polskiego Archiwum Wojennego ${ }^{83}$.

Po odejściu Oppmanowej do pracy w Archiwum Wojskowym w 1932 r., skromnym liczebnie Oddziałem PAW kierował bibliotekarz Stanisław Zieliński $^{84}$. Jego dążeniem było całkowite uporządkowanie i opracowanie zbiorów w celu udostępnienia czytelnikom. W ostatnim zachowanym, drukowanym sprawozdaniu z pracy CBW, od marca 1931 r. do marca 1932 r., podano, że stan skatalogowania i zinwentaryzowania zbiorów PAW wyglądał następująco: gotowych do udostępnienia było 3784 tomy czasopism, 266 rękopisów i 78925 wycinków. Do opracowania pozostało 4298 broszur, 231 tomów prasy ulotnej, 29998 odezw i druków ulotnych, 5582 wycinki oraz 178 voluminów rękopisów ${ }^{85}$. W 1931 r. na prawach rękopisu ukazał się „Inwentarz rękopisów Centralnej Biblioteki Wojskowej i Polskiego Archiwum Wojennego"86. Jednocześnie opracowywano bibliografię prasy okopowej, katalog czasopism PAW według układu geograficznego oraz sporządzono katalog dubletów czasopism. Uporządkowane zostały czasopisma ulotne, druki ulotne oraz odezwy. Prace mimo wszystko postępowały powoli, szczególnie jeśli chodziło o archiwalia, gdyż jak stwierdził w 1933 r. kpt. Stanisław Librewski z Wojskowego Biura Historycznego - zajmował się tym jedynie Stanisław Zieliński ${ }^{87}$. Tenże Librewski dokonał ogólnej charakterystyki archiwaliów PAW, zwracając uwagę na - jego zdaniem - szczególnie cenne dokumenty Związku Strzeleckiego, Strzeleckich Oddziałów Żeńskich, Legionu Wschodniego, NKN, Legionów Polskich, pułków polskich w armii austriackiej, niemieckiej i wojskach koalicyjnych ${ }^{88}$.

Do CBW cały czas trafiały dary włączane do zbiorów PAW, m.in. z Biblioteki Wyższej Szkoły Handlowej oraz Archiwum Wojskowego. Także, jeżeli darowizny osób prywatnych były materiałami ulotnymi, drukami, pismami czy fotografiami dotyczącymi I wojny światowej - Legionów Polskich, Strzelca, Drużyn Strzeleckich, I Korpusu Polskiego - włączano je do PAW ${ }^{89}$.

Nadszedł wrzesień 1939 r., niemiecki atak na Rzeczpospolitą i oblężenie Warszawy. Część zbiorów CBW udało się zapakować i przewieźć do Fortu Legionów na Żoliborzu oraz podziemnych magazynów Biblioteki Publicznej przy ul. Koszykowej. Niemieckie naloty na stolicę w dniach 24-27 września wywołały pożar południowego skrzydła gmachu Generalnego Inspektoratu Sił Zbroj-

\footnotetext{
${ }^{83}$ Instrukcja dla porządkowania druków ulotnych Polskiego Archiwum Wojennego, Wojskowy Instytut Naukowo-Wydawniczy, Warszawa 1930.

${ }^{84}$ B. Bartczak, op.cit., s. 172.

${ }^{85}$ Ibidem.

${ }^{86}$ J. Semkowiczowa, op.cit., s. 72. Informacji Semkowiczowej nie potwierdzają opracowania dot. dziejów CBW. Trudno ustalić, czy jest to wspomniany wcześniej katalog, którego jeden egzemplarz przekazano do Instytutu Hoovera, oba różnią się tytułami.

${ }^{87}$ CAW, zespół akt Archiwum Wojskowe, sygn. I.341.2.99.

${ }^{88}$ Ibidem.

${ }^{89}$ A. Gąsiorowska, M. Lewnau, K. Piwowarska, op.cit., s. 49.
} 
nych przy Al. Ujazdowskich 1, w którym mieściło się CBW. Tam, oprócz PAW, przechowywano również zbiory przywiezionego w 1927 r. do kraju Muzeum Polskiego w Rapperswilu ${ }^{90}$. Archiwalia PAW spłonęły całkowicie, podobnie jak większość pozostałych zbiorów CBW oraz księgozbiór rapperswilski ${ }^{11}$. Uratowane rękopisy, na polecenie niemieckiego komisarycznego kierownika bibliotek okręgu warszawskiego, umieszczono w Bibliotece Ordynacji Krasińskich, którą hitlerowcy doszczętnie spalili w październiku 1944 r. po klęsce powstania warszawskiego. Trudno palące się pergaminy, rękopisy, stare druki polewano łatwopalnym płynem i całkowicie zniszczono. Ocalona pamięć I wojny zginęła bezpowrotnie w drugiej niszczycielskiej wojnie.

Należy dzisiaj szczególnie docenić bezprecedensowy wysiłek włożony w gromadzenie materialnych śladów uczestnictwa polskiego społeczeństwa w I wojnie światowej oraz z uznaniem odnieść się do profesjonalnego przygotowania całej akcji, jej rozmachu oraz nieustającego wysiłku podejmowanego w imię sprawy, nie dla chwały czy zysków. Polskiemu społeczeństwu od dawna nie jest obce organizowanie bibliotek, muzeów, a współcześnie mamy do czynienia z masowym wręcz powstawaniem archiwów społecznych, będących zrywem obywatelskim, jednak akcji gromadzenia źródeł o takim zakresie geograficznym i tematycznym jak PAW, nie było ani wcześniej, ani później.

Tragiczny i nieodwracalny koniec Polskiego Archiwum Wojennego skłania do zastanowienia nad ulotnością pamięci zawartej w dokumentach $\mathrm{w}$ obliczu kataklizmu wojennego. Dzisiaj o niepowtarzalnej inicjatywie PAW, jej ogromnym zasięgu i wielkim zaangażowaniu dziesiątków tysięcy ludzi wiadomo przede wszystkim z materiałów drukowanych i rozpowszechnianych przez tę organizację: sprawozdań, ulotek, odezw i apeli publikowanych na łamach prasy, dokumentacji zachowanej w CBW, CAW oraz katalogu ze zbiorów Instytutu Hoovera. Ale same materiały PAW, ich treść, która miała zaświadczać o polskim uczestnictwie w działaniach I wojny światowej i jej wpływie na społeczeństwo, pozostała nieznana na zawsze. Ich powolne opracowywanie w okresie międzywojennym spowodowało, że nie zostały udostępnione badaczom i wprowadzone do obiegu naukowego. Możemy dzisiaj - wbrew zasadom badań naukowych - „gdybać”, zadając pytanie, czy słusznie Wydział Archiwów Państwowych zrezygnował ze zbiorów PAW, oddając je w całości CBW, czy gdyby zostały przekazane do któregoś archiwum, miałyby szanse ocaleć. Ale przecież zasoby archiwów warszawskich również dotknęły wielkie zniszczenia, jeśli nie we wrześniu 1939 r., to w 1944 r. Jedynie przejęta przez Niemców duża część zasobu Archiwum Wojskowego, w której były m.in. akta legionowe otrzymane od

${ }^{90}$ Wyobrażenie o wielkości zbiorów rapperswilskich daje informacja, że przewożono je w ośmiu piętnastotonowych wagonach. Zob.: http://cbw.wp.mil.pl/pl/8.html [dostęp: 10.09.2018].

91 A. Lewak, Biblioteki Warszawy podczas drugiej wojny światowej, „Rocznik Warszawski” 1961, t. 2, s. 191. 
zarządu PAW w 1920 r., przetrwała wojnę i dzisiaj służy badaniom naukowym - a więc, gdyby?

Paradoksem jest, że pamięć o jednej wojnie, którą chciano ocalić, zniweczyła kolejna. W II wojnie światowej, wojnie totalnej, niemożliwe było podejmowanie podobnych inicjatyw. Walczyły w niej nie tylko armie, jak kilkadziesiąt lat wcześniej, ale doświadczyły jej całe społeczeństwa, w tym szczególnie polskie, którego dorobek kulturowy przeszłości, pamięć zawarta w dokumentach, były świadomie niszczone. Prawdopodobnie tragiczne doświadczenia II wojny światowej także miały wpływ na fakt, że zaczęto zabezpieczać najcenniejsze dobra kultury, takie jak książki i archiwalia, mikrofilmując je, a współcześnie masowo digitalizując nie tylko w celu ułatwienia bezpośredniego dostępu do nich. Czy to jednak dostateczne zabezpieczenie w razie nowej wojny, cyberwojny?

\section{Źródla}

Centralne Archiwum Wojskowe

- Kolekcja Wojskowej Komisji Archiwalnej, sygn. VIII. 807.29.4.

- zespół akt Archiwum Wojskowe, sygn. I.341.2.99.

Hoover Institution, Polish Military Archives, Catalog of pamphlets, leaflets and periodicals at the archives.

Waligóra Bolesław, Zarys wysiłku około gromadzenia pamiętników, wspomnień, relacyj itp. do historii przedwojennych polskich związków wojskowych, formacyj i wojska polskiego, Warszawa 1938, mps na prawach rkps.

Cele i zadania Polskiego Archiwum Wojennego, druk, Kraków 1917.

Instrukcja dla porzadkowania druków ulotnych Polskiego Archiwum Wojennego, Wojskowy Instytut Naukowo-Wydawniczy, Warszawa 1930.

Instrukcya Komitetu Polskiego Archiwum Wojennego (dla piszacych wspomnienia, dzienniczki i pamiętniki), druk [1915].

Odezwa Komitetu [1915], oryginał w zbiorach Centralnego Archiwum Wojskowego (CAW), kopia, [w:] W.K. Roman, Centralne Archiwum Wojskowe 1918-1998 - tradycje, historia, wspótczesność stużby archiwalnej Wojska Polskiego, Torun 1999, załącznik 1.

Odezwa w sprawie zbierania materiatów do folkloru wojennego, „Głos Rzeszowski” z 1 lipca $1917 \mathrm{r}$.

Piechota R., Jagiełło B., Motas M., Pierwsze protokoły Rady Archiwalnej (1918-1922), „Teki Archiwalne" 1971, t. 13, s. 103-193.

Polskie Archiwum Wojenne, „Kurier Lwowski” z 15 sierpnia 1915 r.

Polskie Archiwum Wojenne, ulotka, lipiec 1916 r., https://polona.pl/item/polskie-archiwum-wojenne-inc-wojna-swiatowa-powolala-do-zycia-szereg-nowych,NTkyODI3OTc/0/\#info:metadata [dostęp: 8.09.2018].

Polskie Archiwum Wojenne. Sprawozdanie zarzadu za lata 1917-1918, „Gazeta Lwowska” 1919, nr 222, s. 3. 
Reskrypt Rady Regencyjnej z dnia 31 lipca 1918 roku o organizacji archiwów państwowych i opiece nad archiwaliami, [w:] S. Sierpowski, D. Matelski, Dzieje archiwistyki polskiej. Wybór źródet, t. 1, Poznań 1988, s. 9-20.

Sierpowski S., Matelski D., Dzieje archiwistyki polskiej. Wybór źródet, t. 1, Poznań 1988.

Sprawozdanie Zarzadu Polskiego Archiwum Wojennego (1915-1916) (od 17 stycznia 1915 do 31 grudnia 1916), druk, Kraków 1917.

\section{Bibliografia}

Bartczak B., Stanisław Zieliński, bibliotekarz, bibliograf, publicysta, Torun 1998.

Gąsiorowska A., Lewnau M., Piwowarska K., Centralna Biblioteka Wojskowa 1919-1999. Kalendarium, Warszawa 1999.

Horodyska E.M., Centralna Biblioteka Wojskowa w latach 1919-1932 i jej rola w organizacji bibliotek wojskowych w Polsce, Warszawa 1966.

Kołodziej E., Zarys dziejów Archiwum Akt Nowych w latach 1919-2008, Warszawa 2008.

Konieczny Z., Dzieje archiwum przemyskiego i jego zasobu, Przemyśl 1989.

Kronika CBW, ,Komunikat Bibliograficzny” 1926, nr 1, s. 28.

Kronika, „Przegląd Historyczno-Wojskowy” 1929, t. 1, s. 186-187.

Kuczyński S.K., Regina Oppmanowa (29 I 1905-15 IX 1980), „Archeion” 1982, t. 74, s. 248-250.

Laskowski O., Pawłowski B., Badania dawnej polskiej historii wojskowej. Zadania pracy i ogólna charakterystyka źródet, Warszawa 1927.

Lewak A., Biblioteki Warszawy podczas drugiej wojny światowej, „Rocznik Warszawski” 1961, t. 2, s. 189-220.

Maternicki J., Idee i postawy. Historia i historycy polscy 1914-1918, Warszawa 1975.

Pomnażajmy zbiory Polskiego Archiwum Wojennego, „Ilustrowany Kurier Codzienny”, nr 216 z 6 sierpnia 1934 r., s. 9.

Roman W.K., Centralne Archiwum Wojskowe 1918-1998 - tradycje, historia, współczesność stużby archiwalnej Wojska Polskiego, Torun 1999.

Semkowicz W., W sprawie gromadzenia materiałów z wojny światowej, „Nauka Polska, jej potrzeby, organizacja i rozwój” 1932, t. 16, s. 90.

Semkowicz W., Polskie Archiwum Wojenne, „Tygodnik Literacko-Społeczny Pion” [Warszawa], 1935, r. 3, nr 23(88), s. 12.

Semkowiczowa J., Polskie Archiwum Wojenne (Dzieje instytucji), „Archeion” 1966, t. 45, s. 63-74.

Sprawy Towarzystwa, „Kwartalnik Historyczny” 1915, nr 29, s. 480.

Wierczyński S., Kto ma jakie pamiątki z czasu wojny światowej, „Kurier Poznański” nr 173 z 14 kwietnia 1928 r., s. 8.

Witwicki W., Polskie Archiwum Wojenne, „Ilustrowany Tygodnik Polski” [Kraków] nr 6 z 5 września 1915 r., s. 98-99. 